\title{
Imiona chrześcijańskie w Synodyku nowogrodzkim z końca XIV-XV wieku
}

\author{
Christian names in the Novgorod synodicon \\ from the end of the $14^{\text {th }}$ century to the $15^{\text {th }}$ century
}

\begin{abstract}
The article contains an analysis of Christian names selected from the oldest synodicon written in the Lisitsky monastery near Veliky Novgorod. The analysis comprises 3190 names of lay people, amongst which are 208 male names and 58 female names. The author discusses the group of given names (basic forms, their phonetic, morphological variants and frequency, as well as rarely used names that occurred in the synodicon).
\end{abstract}

Keywords: Novgorod personal names, Old Russian Christian names, Novgorod synodicon, commemoration book of Lisitsky monastery

Marian Wójtowicz, Uniwersytet im. Adama Mickiewicza w Poznaniu, Poznań - Polska, maw@ amu.edu.pl, ORCID ID: https://orcid.org/0000-0002-5657-7787

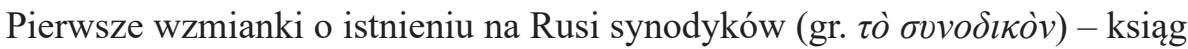
pamięci o zmarłych, pochodzą z początku XII wieku. Latopis tawrentjewski podaje pod rokiem 1108 wiadomość o wpisie do synodyka imienia ihumena Teodozego: ,... и нача възвъщати князю С(вя)тополку дабы вписаль Феодосья в сънаникъ; [...] повель митрополиту вписати в синодикъ" (Karskij 283), przytacza ją także Latopis hipacki (ipatjewski): „....нача понуждати Феоктисть С(вя)тополка кн(я)зя вопсати Федосья в синаникъ [...] и велъ и вписати в сънаникъ” (Šahmatov 259). Upamiętnianie w synodykach imion władców, dostojników kościelnych oraz osób żyjących i umarłych było w owym czasie powszechną praktyką i nieodłączną częścią życia religijnego. Ihumen Daniel, który w latach 1106-1108 odbył podróż do Ziemi Świętej, pisze, że umieścił w synodyku „имена князей рускых [...] в лаврђ у святаго Савы; и нынђ поминаются имена их во октении, с женами и с дътьми их. [...] И отпьхом литургии за князи русскыя и за вся христианы 50 литургий; а за усопшаа 40 литургий отпъхом" (Prohorov 114). 
Szczególnie rozpowszechnionym typem synodyka były tzw. pomianniki (strus. помяньникъ, ros. поминальник) zawierające wykazy imion osób wspominanych podczas nabożeństw odprawianych w intencji tak żyjących, jak i zmarłych. Prowadzono je w wielu cerkwiach i klasztorach, a wpisu osób dokonywano za ofiarowane znaczne sumy pieniężne lub przekazywane dobra ziemskie.

Najstarszy zachowany synodyk powstał w klasztorze lisickim położonym na niewielkim wzgórzu, nazywanym Lisią Górką (Лисицья горка), na lewym brzegu Małego Wołchowca pod Nowogrodem. Nieistniejący dziś klasztor był jednym z ważnych ośrodków pisarskich, jednakże w XVIII wieku podupadł i działalność skryptorium ustała (Semenov 369-373; Bobrov 78-98). Synodyk powstał po roku 1390, liczy 155 kart i ma niejednolitą strukturę. Tekst podstawowy (pierwotny) został ułożony i spisany przez mnicha Pumina (Pimiena), który synodyk określił nazwą вседеньникъ (tj. codzienny). Pozostałe części tekstu są wynikiem pracy kilku innych pisarzy. Synodyk lisicki nie został dotychczas w całości wydany. Obszerne fragmenty, zawierające bogaty materiał imienniczy, zamieściła w pracy poświęconej charakterystyce i analizie treści nowogrodzkich synodyków T.I. Szabłowa (Šablova 69-87). Tekst został podany w pracy w uproszczonej transkrypcji za pomocą współczesnego alfabetu rosyjskiego.

Zapisane w synodyku imiona można podzielić na dwie grupy: 1) imiona osób duchownych, nowogrodzkich arcybiskupów, archimandrytów, ihumenów, kapłanów, braci zakonnych i ascetów, 2) imiona osób świeckich, donatorów i członków ich rodzin. Imion duchownych jest znacznie mniej aniżeli imion świeckich. Ze względu na swoją specyfikę, imiona duchownych, które mogą stanowić osobny problem badawczy, nie są tu rozpatrywane. U osób świeckich zapisanych w synodyku odnotowano 3190 imion chrześcijańskich. W tej liczbie mieści się 2250 imion męskich i 940 imion żeńskich. W grupie imion męskich zostało poświadczonych 208 imion - odrębnych jednostek leksykalnych, natomiast wśród imion żeńskich - 58 osobnych imion. Imion męskich jest tu niemal czterokrotnie więcej niż żeńskich. Liczebna przewaga imion męskich nad żeńskimi odzwierciedla proporcję obu grup w zasobie imion kanonicznych ujętych w kalendarzu cerkiewnym, w którym imion męskich jest również cztery razy więcej niż imion żeńskich. Przytoczone liczby są także wskaźnikiem stopnia wykorzystania zasobu imion cerkiewnych nadawanych na chrzcie. Liczba odrębnych imion męskich świadczy o wykorzystaniu $25 \%$ tego zasobu, natomiast liczba imion żeńskich wskazuje na wykorzystanie $28 \%$ ogólnej ich liczby w kalendarzu. Warto zauważyć, że w okresie staroruskim do XV wieku włącznie w użyciu było ok. 200 męskich imion chrześcijańskich (Skulina 66; Wójtowicz 1986: 21).

Imiona w synodyku zapisywano w postaci podstawowej (prymarnej) z reguły $\mathrm{w}$ formie biernika lp. Zapis imion poprzedzała powtarzająca się w tekście formu- 
ła: Помяни, Господи, душа (умерших) рабъ Своихъ lub Помяни, Господи, душу усопмаго раба Своего (раба Божия), po której następowała długa lista imion oddzielonych od siebie kropką. Rzadziej pojawia się formuła: ( $A$ ce) за вздоровьe z zapisem imion w dopełniaczu. Część imion wykazuje pod względem formy znaczne różnice. Niektóre są reprezentowane przez formę cerkiewnosłowiańską lub do niej zbliżoną i jednocześnie przez formy ruskie, używane w języku potocznym. Można tu wymienić (cyfra w nawiasach oznacza liczbę zapisanych form), nр.: Eустафеи (4), Остафеи (6), Остафья (14); Еустратеи (1), Острат (1); Елеуфереи (1), Елуфереи (2), Елфереи (4), Олуфереи (4), Олфереи (8), Уферии (1); Иоан, Иоанн (59), Еван (2), Иван (115); Иосиф (1), Иесиф (2), Есип (3), Есиф (28), Осиф (7); Ксенофонт (1), Селифонт (3), Сенофонт (1); Симеон (2), Семеон (15), Семен (16), Смен (17). Podobne różnice form obserwuje się w grupie imion żeńskich, np.: Евгения (1), Евгенья (2), Еугения (1), Еугенья (1), Овгенья (4); Евфросиния (1), Еуфросенья (1), Ефросенья (4), Опрасенья (1), Опросенья (3), Офросинья (1); Ирина (1), Ириния (5), Иринья (15), Орина (5); Февронья (8), Ховронья (1); Фотинья (1), Фетенья (13), Фетинья (5), Хотения (1). Pewna część imion została zapisana wyłącznie w postaci potocznej, np. imiona męskie: Амбакум (1), Обакум (2), Обакун (1) - Аввакум; Амбросим (1), Омбросим (1) - Амвросий; Алампеи (1) - Евлампий; Еникии (1) - Евникей, Евникиан; Онтуфеи (2) - Евтихий, oraz imiona żeńskie: Алумпия (1) - Олимпия; Киликия (1) - Кикилия; Ографена (1), Огрофена (3), Огруфена (12), Огруфенья (2) - Агриппина; Оксенья (19), Оксинья (3) - Ксения; Олена (20) - Елена; Олисава (5), Елисава (1) - Елисавета; Паласкирья (1) - Параскева; Полинарья (2), Поминарья (2), Понинарья (5) - Аполлинария; Понинила (1) - Феонилла; Ульяна (42), Улияна (6) - Юлиания itp.

W materiale antroponimicznym synodyka niewielką grupę tworzą oboczne warianty imienia typu Григории || Григорья, Макарии || Макарья. Postaci oboczne pojawiły się w wyniku przejścia rzeczowników na -uu do deklinacji z tematem na -ja, w której obok rzeczowników typu cyduu wskutek unifikacji paradygmatu powstały formy mianownika lp. судия, судья (por. Sobolevskij 1907: 216217; Haburgaev 50-51). Nie można też wykluczyć wpływu imion typu Ананья, Азария, Захарья itp. Należą tu np. imiona: Артемья, Ортемья (4), Григорья (9), Денесья, Денисья (3) - Дионисий; Макарья (6), Нефедья (1) - Мефодий, Назарья (3), Остафья (14), Прокопья (14), Тарасья (1), Юрья (1).

Imiona chrześcijańskie z zakończeniem -ил, nр. Гавриил, Даниил, Михаил występują $\mathrm{w}$ synodyku w bierniku z fleksją $-a$ lub $-y$. Fleksja $-y$ pozwala na rekonstrukcję mianownika z końcówką - $a$, natomiast fleksja - $a$ wskazuje na końcówkę zerową lub -o. Końcówka zerowa jest tu jednak mniej prawdopodobna. Imiona z zakończeniem na - $и л \mathrm{w}$ źródłach nowogrodzkich spotyka się rzadko, np. popularne imię Михаил w Latopisie nowogrodzkim w XIII-XIV wieku zo- 
stało odnotowane zaledwie kilka razy, np. pod 1232, 1259, 1269, 1280, 1398 rokiem (Nasonov 280, 310, 316, 324, 393). Astrid Baecklund zwraca uwagę na brak w XV-wiecznych nowogrodzkich dokumentach kancelaryjnych formy $\mathrm{Mu}$ хаиль u osób świeckich (Baecklund 141-142). Przeważają w nich formy Muxaило (19) і Михаила (10). Taki stan utrzymuje się również w późniejszym okresie. Halina Milejkowska potwierdza częste występowanie form Михаило (20) і Михаила (15) oraz form Кирила (-) і Кирило (-) $)^{1}$ w nowogrodzkich księgach zaprzedawania się w poddaństwo (tzw. кабальные книги) z przełomu XVI i XVII wieku (Milejkowska 391, indeks). W synodyku odnotowano następujące formy imion: Гаврила (9), Гавирило (9); Данила (7), Данило (12); Измаила (2); Кирила (4), Курила (2), Кюрила (7), Кирило (6); Мануила (3), Мануило (2); Михаила (27), Михала (2), Михаило (26); Самуила (4), Самоило (4), Самуило (1).

Zgromadzony w synodyku materiał antroponimiczny umożliwia określenie częstości występowania poszczególnych imion oraz ocenę różnic w ich popularności. Imiona męskie pod tym względem można podzielić na dwie grupy: 1) imiona najczęstsze (176-23 zapisy w tekście) i 2) imiona częste (21-15 zapisów). Po każdym imieniu należącym do pierwszej grupy, podanym w postaci współczesnej i oznaczonym kolejnym numerem, przytacza się liczbę zapisów w synodyku, a dla porównania w nawiasach miejsce zajmowane w tabeli częstości imion Baecklund (Baecklund 88) oraz miejsce w spisie sporządzonym na podstawie indeksu w cytowanym artykule Milejkowskiej (Milejkowska 390-393). Grupa najczęstszych imion została ograniczona do 21, ponieważ umożliwia to porównanie $\mathrm{z}$ taką samą liczbą imion ujętych w tabeli Baecklund. W skład tej grupy wchodzą następujące imiona: 1. Иван (Иоанн) $176(1,1), 2$. Василий 90 (2, 3), 3. Григорий $89(3,6), 4$. Федор $56(4,2), 5$. Михаил $55(8,7), 6$. Степан 54 (7, 10), 7. Яков 51 (6, -), 8. Семен $50(5,8), 9$. Юрий (Георгий) 46 (9, -), 10. Иосиф 41 (10, -), 11. Павел 39 (14, -), 12. Андрей 33 (12, 11), 13. Кузьма (Козма) 33 (17, -), 14. Матвей 32 (13, -), 15. Тимофей 32 (-, 13), 16. Никифор (Микифор) $26(-, 20), 17$. Никита (Микита) 25 (20, 12), 18. Евстафий 24 (-, -), 19. Фома 24 (-, -), 20. Дмитрий 23 (11, -), 21. Максим 23 (18, -).

Wykaz najczęstszych imion wybranych z synodyka jest najbliższy zestawowi imion w tabeli Baecklund tak pod względem składu, jak i kolejności. W pierwszej dziesiątce znalazły się te same imiona, przy czym kolejność pierwszych czterech imion Иван, Василий, Григорий, Федор jest dokładnie taka jak w tabeli Baecklund. Imiona Иван, Василий і Федор zajmują najwyższe miejsca w spisie Milejkowskiej. Do pierwszej dziesiątki, oprócz imion Григорий, Михаил, Семен,

\footnotetext{
${ }^{1}$ Znak minus w nawiasach oznacza brak liczby zapisów poszczególnych imion w źródłach oraz brak imienia w tabeli (spisie) częstości.
} 
Степан, należą w tym spisie Петр, Афанасий, Алексей, których nie ma w obu wymienionych wykazach.

Pozostałe imiona z synodyka i tabeli Baecklund są w dużym stopniu podobne. Różnica dotyczy czterech imion z synodyka, których nie ma u Baecklund: Tuмофей, Никифор, Евстафий, Фома oraz czterech imion z tej tabeli: Алексей, Сидор, Игнатий, Александр, których nie ma w wykazie najczęstszych imion z synodyka. Weszły one do grupy imion częstych i zajmują następujące miejsca: 22. Александр 21 (21, 15), 30. Игнатий 19 (19, -), 32. Сидор 19 (16, -), 35. Алексей $16(15,9)$. Spis Milejkowskiej znacznie różni się od wykazu najczęstszych imion z synodyka składem i kolejnością ich występowania. Wydaje się, że różnicę tę można objaśnić późniejszym chronologicznie materiałem antroponimicznym dotyczącym w większości ludności niewolnej. Warto dodać, że nosicielami wymienionych 21 najczęstszych imion były 1022 osoby, co stanowi 45,4\% ogółu mężczyzn zapisanych w synodyku.

Grupę najczęstszych imion żeńskich wyróżniono na podstawie zakresu ich występowania (108-18 zapisów) w tekście. Liczy ona 20 imion, które porównano z miejscem imienia (oznaczonym cyfrą w nawiasie) w spisie Milejkowskiej; po każdym imieniu podano liczbę zapisów w synodyku. Są to następujące imiona: 1. Мария (Марья) 108 (1), 2. Анна 57 (2), 3. Настасия (Настасья) 49 (-), 4. Юлиания (Улияна, Ульяна) 48 (15), 5. Евдокия (Овдокия, Овдотья) 38 (-), 6. Феодосия (Федосья) 34 (5), 7. Варвара 28 (9), 8. Евфимия (Офимья) 27 (12), 9. Ирина (Иринья, Орина) 26 (10), 10. Агафия (Огафья) 24 (-), 11. Василиса (Василиста) 24 (-), 12. Матрена (Матрона, Матруна) 24 (6), 13. Ксения (Оксенья, Оксинья) 22 (-), 14. Акилина (Окулина) 21 (-), 15. Феодотия (Федотья) 21 (-), 16. Елена (Олена) 20 (-), 17. Фотиния (Фетенья, Фетинья) 20 (-), 18. Наталия (Наталья) 19 (19), 19. Марфа 19 (14), 20. Агриппина (Огрофена, Огруфина) 18 (-). Elementem wspólnym obu wykazów jest 10 imion, wśród których Мария i Анна są na najwyższych miejscach, а Варвара, Ирина, Наталия, Феодосия zajmują bliskie sobie miejsca, natomiast Евфимия, Марфа, Матрена, Юлиания różnią się miejscem najbardziej. Zasadnicza różnica dotyczy dwóch grup imion. Pierwszą grupę tworzy 10 imion z powyższego wykazu, które nie są reprezentowane w spisie Milejkowskiej: Настасия, Евдокия, Агафия, Василиса, Ксения, Акилина, Феодотия, Елена, Фотиния, Агриппина. Do drugiej należy 10 imion z tego spisu o dużej częstości, które nie występują w wykazie najczęstszych imion z synodyka (po imieniu podano liczbę zapisów, w nawiasie kolejne miejsce w spisie). Są to: Пелагея 48 (3), Татьяна 47 (4), Дарья 39 (7), Екатерина (Катерина) 38 (8), Марина 31 (11), Параскева (Парасковья) 30 (13), Юстина (Устимья, Устинья) 28 (16), Соломония (Соломанида) 26 (17), Стефанида 26 (18), Гликерия (Лукерья) 24 (20). Można przypuszczać, że podobnie jak w wypadku najczęstszych imion męskich także tu podstawowa różnica $\mathrm{w}$ zasobie imion 
znajduje uzasadnienie w późniejszej chronologii materiału imienniczego tzw. kabalnych ksiąg nowogrodzkich i społecznej pozycji użytkowników imion. Należy dodać, że użytkownikami 20 najczęstszych imion żeńskich było 647 osób, czyli $68,8 \%$ ogólnej liczby kobiet odnotowanych w synodyku.

$\mathrm{W}$ rozpatrywanym materiale antroponimicznym jest pewna grupa imion, które ze względu na pochodzenie, strukturę, postać fonetyczną lub morfologiczną wymagają krótkiego komentarza. Są to następujące imiona (w nawiasach podano ich liczbę):

1. Богдан (1) - słowiańskie imię złożone traktowane zapewne jako kalka

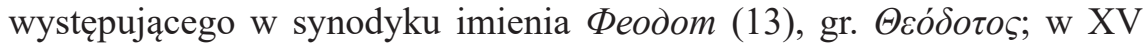
wieku rzadkie (Baecklund 44) - Богдан (4). Imię uważane w XVI-XVII wieku za pogańskie (Uspenskij 1969: 204), popularne w Nowogrodzie, jednakże nie wśród chołopów (Milejkowska 380); spotyka się niekiedy obok imienia chrzestnego, np. Костянтин Богдан Федоров сын Юрьевичя [Фомин], akt nr 119, 1522 rok (Bahrušin 112).

2. Борис (21) znacznie częstsze od imienia Глеб (4), podobnie na Rusi Moskiewskiej w XIV-XV wieku i później (Wójtowicz 1986: 25); częste w Nowogrodzie w XV wieku (Baecklund 44) - Борис (16); św. Borysa uważano za patrona zapewniającego pomyślność i zysk (Fasmer 194).

3. Васиса (6) - wariant imienia Василиса (24) z elizją sylaby -ли-. Imię Baсиса (-) notuje w indeksie Milejkowska (Milejkowska 393).

4. Верига (1) - hagionimiczny element leksykalny związany z nazwą uroczystości religijnej ku czci św. Piotra (Праздник Петровых вериг) obchodzonej 16 stycznia; por. вериги 'żelazne okowy, kajdany', верига 'łańcuch'; był pojmowany zapewne jako przydomek świętego, używany w zastępstwie imienia, który z czasem się usamodzielnił, podobnie jak np. Воин (Иоанн), Кущник (Иоанн), Постник (Иоанн), Тирон (Феодор), Зилот (Симон) (Wójtowicz 1996). Nazwa rozpowszechniona w XVI wieku (Tupikov 139), występuje często wraz z imieniem Пemp (Veselovskij 66).

5. Володимер (1) - rodzime imię złożone, odpowiednik kanonicznego Владимир.

6. Волос (2) - wariant występującego również w synodyku imienia Власий (7). Imię znane z dokumentów nowogrodzkich, np.: gramoty $\mathrm{nr} 103$, do 1147 roku (Valk 160), nr 104, ok. 1192 roku (Valk 161), gramoty na brzozowej korze nr 914, 2. poł. XI wieku (Ânin, Zaliznâk, Gippius 105); nr 604, 2. poł. XII wieku (Ânin, Zaliznâk 1986: 67); nr 50, XIV wiek (Arcihovskij 53), Latopisu nowogrodzkiego, zapis pod 1187 rokiem i 1230 rokiem (Nasonov 38, 69). Do imion chrześcijańskich zalicza postać Волос Boris M. Lapunow (Lâpunov 315-316) і Tadeusz Skulina 
(Skulina 68); według Vasmera nie można utożsamiać etymologicznie Волосъ і Віর́бıоৎ (Fasmer 343). Sobolewski uznaje je za imię świeckie (Sobolevskij 1910: 251). Andriej A. Zalizniak (Zaliznâk 283) uważa, że pogańskie imię Волос stało się ekwiwalentem imienia św. Własija.

7. Eупатии (1) - imię odnotowane w kalendarzu cerkiewnym z XIII wieku pod datą 16 listopada (Makarij, mitr. 587), utożsamiane z imieniem Ипатий. Nosił je biskup Hipacy z Gangry (Ипатий Гангрский), którego wspomnienie w wielu kalendarzach przypada w wymienionym wyżej dniu (Loseva 203). Por. też zapisy nazwy cerkwi w Latopisie nowogrodzkim pod 1183 rokiem: цьркковь святого Еупатия (Nasonov 37); w gramocie nr 117, poł. XV wieku: святаго Еупатия (Valk 176), zapis nazwy klasztoru w Kostromie w akcie nr 229, 1443 rok: Eynam(b)ева \| Иnam(b) ева манастыря игумен, ...nод Елnат(ь)емъ; nr 230, ok. 1463-1464 roku: святому Еупатию $\|$ Ельпатью (С̆еrepnin 250, 251).

8. Warianty imion Киприан (4) || Кюприян (4); Кир (2) || Кур (1) || Кюр (4) і Кирил (6) || Кирила (4) || Курила (2) || Кюрила (7) są wynikiem dywergentnej substytucji gr. $v$.

9. Imię Kum (1) jest wariantem występującego w synodyku Tum (3), zob. też Sobolevskij 1907: 133; Unbegaun 49.

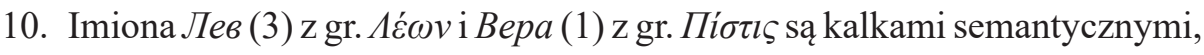
które weszły do zasobu imion chrzestnych.

11. Нерон (2) - wariant imienia Иерон, które notuje kalendarz Ewangeliarza Mścisława, do 1117 roku (Žukovskaâ 235), pod datą 7 listopada; nagłos zmienił się pod wpływem imion na Не-. W postaci Нерон imię wymienia pod tą samą datą wspomniany kalendarz z XIII wieku (Makarij, mitr. 586), zob. też Loseva 195. Boris A. Uspienskij (Uspenskij 1971: 488; 1994: 155) i Boris O. Unbegaun (Unbegaun 54) uważają, że jest ono modyfikacją imienia Мирон.

12. Фларь (1) - wariant imienia Флор (1), Фрол (2) znany np. z gramot na brzozowej korze nr 615, XIII wiek (Ânin, Zaliznâk 1993: 21), nr 262, 263, XIV wiek (Arcihovskij, Borkovskij 88, 90).

13. Niezwykle rzadkie są w synodyku imiona skrócone, np. Пантелеu (3): Пантелеимон і Спир (1): Спиридон (2). Niektóre skrócenia uzyskały zakończenie -eu pod wpływem pełnych form, np.: Парфей (1) - Парфенеи, Севастеи (1) - Севастиан, Калентеи (2) - Каллиник, pot. Каленик, z zakończeniem -mей pod wpływem Мелентей, Парфентей, Софонтей itp.

14. Odnotujmy jeszcze imię Правотарx (1), które jest tworem powstałym w wyniku omyłkowego połączenia dwóch imion Пров i Tapx, występujących w kalendarzu cerkiewnym obok siebie (Uspenskij 1969: 203). 
Analiza zebranego materiału prowadzi do kilku wniosków. Synodyki są ważnym źródłem znacznie poszerzającym podstawę materiałową do badań nad imionami chrześcijańskimi. Zgromadzony w nich materiał antroponimiczny nie został jeszcze wystarczająco poznany. Spisany przez mnicha klasztoru lisickiego Pimena synodyk zawiera obszerne wykazy imion używanych przez osoby duchowne i świeckie pod koniec XIV i w XV wieku w Nowogrodzie Wielkim. Szczególnie licznie jest reprezentowane w nim imiennictwo świeckie. Imiona męskie przeważają nad zbiorem imion żeńskich, które w innych dokumentach z tego okresu, co warto zaznaczyć, rzadko występują w tak dużej jak w tym synodyku liczbie. Cechuje je znaczna różnorodność form. Obok postaci cerkiewnosłowiańskich występują potoczne formy imion, wyjątkowe są imiona skrócone i kalki imion greckich. Imiona poszczególnych osób zapisywano w postaci podstawowej (prymarnej), zazwyczaj w bierniku. Forma imienia, podawanego do zapisu zapewne ustnie, zależała w dużym stopniu od poziomu umiejętności pisarza, jego kompetencji czy też uznania. Przedstawiona tu problematyka imion chrześcijańskich nie wyczerpuje rzecz jasna całego zagadnienia. Zebrany materiał antroponimiczny umożliwił jedynie w części ukazanie mało dotychczas znanego fragmentu imiennictwa nowogrodzkiego.

\section{Bibliografia}

Ânin, Valentin Lavrent'evič, Andrej Anatol'evič Zaliznâk. Novgorodskie gramoty na bereste (iz raskopok 1977-1983 gg.). Moskva, Nauka, 1986.

Ânin, Valentin Lavrent'evič, Andrej Anatol'evič Zaliznâk. Novgorodskie gramoty na bereste (iz raskopok 1984-1989 gg.). Moskva, Nauka, 1993.

Ânin, Valentin Lavrent'evič, Andrej Anatol'evič Zaliznâk, Aleksej Alekseevič Gippius. Novgorodskie gramoty na bereste (iz raskopok 1997-2000 gg.). Moskva, Russkie slovari, 2004.

Arcihovskij, Artemij Vladimirovič. Novgorodskie gramoty na bereste (iz raskopok 1952 g.). Moskva, Izdatel'stvo Akademii Nauk SSSR, 1954.

Arcihovskij, Artemij Vladimirovič, Viktor Ivanovič Borkovskij. Novgorodskie gramoty na bereste (iz raskopok 1956-1957 gg.). Moskva, Izdatel'stvo Akademii Nauk SSSR, 1963.

Baecklund, Astrid. Personal names in medieval Velikij Novgorod, I. Common names, Stockholm, Almqvist \& Wiksell, 1959.

Bahrušin, Sergej Vladimirovič, red. Akty feodal'nogo zemlevladeniâ i hozâjstva XIV-XVI vekov. T. 1. Moskva, Izdatel'stvo Akademii Nauk SSSR, 1951.

Bobrov, Aleksandr Grigor'evič. „Knigopisnaâ masterskaâ Lisickogo monastyrâ (konec XIV - pervaâ polovina XV v.)". Knižnye centry Drevnej Rusi. XI-XV vv. Raznye aspekty issledovaniâ. Red. Dmitrij Sergeevič Lihačev. Sankt-Peterburg, Nauka, 1991, s. 78-98.

Čerepnin, Lev Vladimirovič, red. Akty social'no-èkonomičeskoj istorii Severo-Vostočnoj Rusi konca XIV-načala XVI v. T. 3. Moskva, Nauka, 1964.

Fasmer, Maks. Ėtimologičeskij slovar' russkogo âzyka. T. 1. Perevod s nemeckogo i dopolneniâ O.N. Trubačev. Moskva, Progress, 1964. 
Haburgaev, Georgij Aleksandrovič. Očerki istoričeskoj morfologii russkogo âzyka. Imena. Moskva, Izdatel'stvo Moskovskogo universiteta, 1990.

Karskij, Evfimij Fedorovič, red. Lavrent'evskâ̂ letopis'. Polnoe sobranie russkih letopisej. T. 1. Moskva, Izdatel'stvo Akademii Nauk SSSR, 1962.

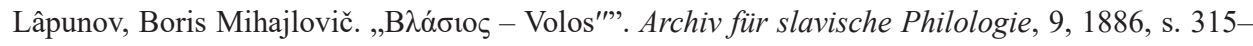
316.

Loseva, Ol'ga Viktorovna. Russkie mesâceslovy XI-XIV vekov. Moskva, Pamâtniki istoričeskoj mysli, 2001.

Makarij, mitr. (Bulgakov). Istoriâ Russkoj Cerkvi. T. 2. Moskva, Izdatel'stvo Spaso-Preobraženskogo Valaamskogo monastyrâ, 1995.

Milejkowska, Halina. „Przyczynek do badań nad imionami własnymi mieszkańców Nowogrodu na przełomie XVI i XVII wieku”. Slavia Orientalis, 11, 1, 1962, s. 367-396.

Nasonov, Arsenij Nikolaevič, red. Novgorodskaâ pervaâ letopis' staršego i mladšego izvodov. Moskva-Leningrad, Izdatel'stvo Akademii Nauk SSSR, 1950.

Prohorov, Gelian Mihajlovič, oprac. „«Hoždenie» igumena Daniila”. Pamâtniki literatury Drevnej Rusi, XII vek. Red. Lev Aleksandrovič Dmitriev, Dmitrij Sergeevič Lihačev. Moskva, Hudožestvennaâ literatura, 1980, s. 25-116.

Šablova, Tat'âna I. Novgorodskie sinodiki XIV-XVII vekov. Sankt-Peterburg, Aletejâ, 2017.

Šahmatov, Aleksej Aleksandrovič, red. Ipat'evskaâ letopis'. Polnoe sobranie russkih letopisej. T. 2. Moskva, Izdatel'stvo vostočnoj literatury, 1962.

Semenov, Aleksandr Ignat'evič. „Lisickij monastyr' - prigorodnyj centr novgorodskogo knigopisaniâ". Trudy Otdela drevnerusskoj literatury, t. 17. Red. Nataliâ Aleksandrovna Kazakova. Moskva-Leningrad, Izdatel'stvo Akademii Nauk SSSR, 1961, s. 369-373.

Sinodik novgorodskogo Lisickogo monastyrâ. Web. 14.11.2020. http://rgada.info/kueh/index. $\mathrm{php} ? \mathrm{~T} 1=\& \mathrm{Sk}=30 \&$ page $=9$.

Skulina, Tadeusz. Staroruskie imiennictwo osobowe. T. 2. Wrocław-Warszawa-Kraków-Gdańsk, Zakład Narodowy im. Ossolińskich, 1974.

Sobolevskij, Aleksej Ivanovič. Lekcii po istorii russkogo âzyka. Moskva, Universitetskaâ tipografiâ, 1907.

Sobolevskij, Aleksej Ivanovič. Materialy i issledovaniâ v oblasti slavânskoj filologii i archeologii. Sbornik Otdeleniâ russkogo âzyka i slovesnosti Imperatorskoj Akademii Nauk, 88, 3. Sankt-Peterburg, Tipografiâ Imperatorskoj Akademii nauk, 1910.

Tupikov, Nikolaj Mihajlovič. Slovar' drevnerusskih ličnyh sobstvennyh imen. Zapiski Otdeleniâ russkoj i slavânskoj arheologii Imperatorskogo Russkogo arheologičeskogo obŝestva. T. 6. Sankt-Peterburg, Tipografiâ I. A. Skorohodova, 1903.

Unbegaun, Boris O. Russkie familii. Moskva, Progress, 1989.

Uspenskij, Boris Andreevič. Iz istorii russkih kanoničeskih imen (istoriâ udareniâ v kanoničeskih imenah sobstvennyh $v$ ih otnošenii $k$ russkim literaturnym i razgovornym formam). Moskva, Izdatel'stvo Moskovskogo gosudarstvennogo universiteta, 1969.

Uspenskij, Boris Andreevič. „Mena imen v Rossii v istoričeskoj i semiotičeskoj perspektive”. Trudy po znakowym sistemam. Učenye zapiski Tartuskogo gosudarstvennogo universiteta, 284, 1971, s. $481-492$.

Uspenskij, Boris Andreevič. Izbrannye trudy. T. 2: Âzyk i kul'tura. Moskva, Gnozis, 1994.

Valk, Sigizmund Natanovič, red. Gramoty Velikogo Novgoroda i Pskova. Moskva-Leningrad, Izdatel'stvo Akademii nauk SSSR, 1949.

Veselovskij, Stepan Borisovič. Onomastikon. Drevnerusskie imena, prozviŝa i familii. Moskva, Nauka, 1974. 
Wójtowicz, Marian. Drevnerusskaâ antroponimiâ XIV-XV vv. Severo-Vostočnaâ Rus'. Poznań, Wydawnictwo Naukowe UAM, 1986.

Wójtowicz, Marian. „O hagionimicznych elementach leksykalnych w antroponimii rosyjskiej”. Antroponimia słowiańska. Red. Ewa Wolnicz-Pawłowska, Jerzy Duma. Warszawa, Slawistyczny Ośrodek Wydawniczy, 1996, s. 353-361.

Zaliznâk, Andrej Anatol'evič. Drevnenovgorodskij dialekt. Moskva, Âzyki slavânskoj kul'tury, 2004.

Žukovskaâ, Lidiâ Petrovna, red. Aprakos Mstislava Velikogo. Moskva, Nauka, 1983. 